\title{
Measuring Thickness of Object with Ultrasonic Thickness Gauge
}

\author{
Fuao Han $^{1}$, Li Zhang ${ }^{1, a}$ and Kaige Cui ${ }^{2}$ \\ ${ }^{1}$ School of Physics, Tonghua Normal University, 134000, Tonghua, China, \\ ${ }^{2}$ School of Aeronautical Manufacturing Engineering, Nanchang Hangkong University, 330000, Nanchang, China
}

\begin{abstract}
In this paper, the ultrasonic thickness gauge by the pulse-reflective principle of the steel pipe, the thickness of steel plate, glass and glass were measured and analyzed, and other factors in thickness measurement had certain influence on the thickness measured: coupling agent, surface condition, temperature and so on.
\end{abstract}

\section{Working Principle}

Ultrasonic thickness gauge is mainly composed of two parts, the main engine and the probe. The main engine includes the transmitting circuit, the receiving circuit, the counting display, the keyboard, the central processing unit and so on, its principle is similar with the light wave measurement principle. The ultrasonic pulses emitted by the probe reach the object and propagate in the object and reach the material boundary when the probe is reflected back through the MCU count, the thickness value is displayed by the liquid crystal display, which is mainly based on the propagation velocity of the sound wave in the object multiplied by half of the time through the object. As shown in the following

$$
\mathrm{T}=2 \mathrm{H} / \mathrm{v}
$$

H--t--thickness ,V---material sound velocity measurement of ultrasonic wave received and emitted.

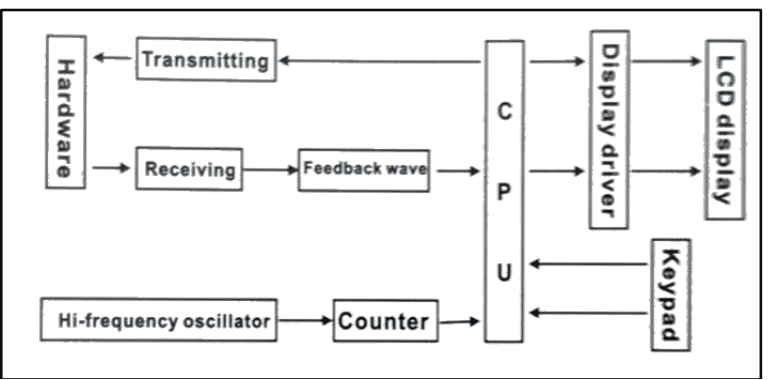

Figure 1. How to work.

\section{Using Methods}

\subsection{Preparation before measurement}

Probe plug into the host probe socket, boot, the main display display last shutdown before the sound speed used and the thickness of the storage unit number, at this point can start measurement, sound speed and adjust press vel key into the sound velocity adjustment, screen display $\mathrm{m} / \mathrm{s}$ and the current speed of sound value, at this time vel flashing.

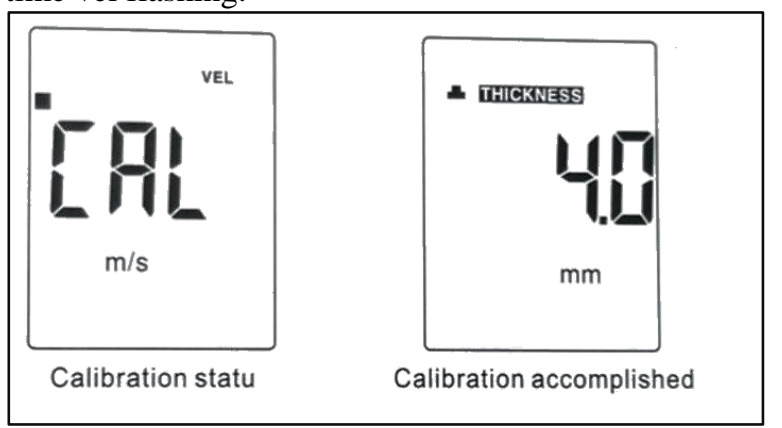

Figure 2. Calibration.

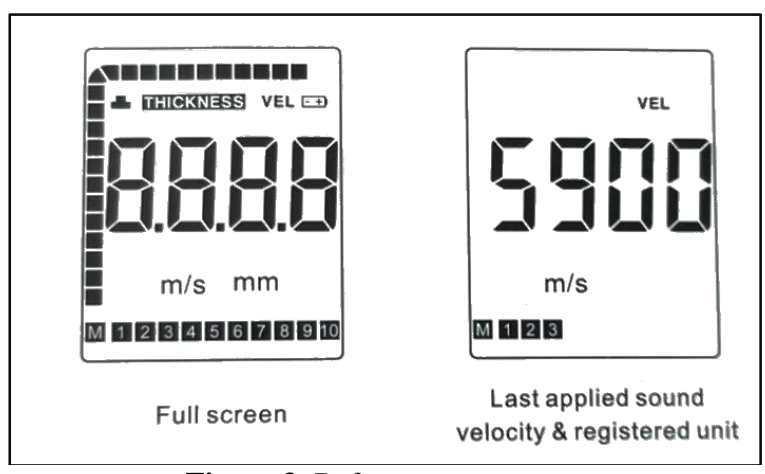

Figure 3. Before measurement.

\subsection{Calibration}

After each replacement probe, the battery should be calibrated, long press cal key into the calibration status.

\subsection{Thickness measurement}

The coupling agent is applied to the measured place, the probe iscoupled with themeasured material to measure,and the screen shows the thickness of the object. 


\subsection{Acoustic speedmeasurement}

First Use vernier caliper, such as measuring the thickness of the goods, and then use the ultrasonic thickness gauge to measure the material, and then use the thickness unit adjustment key to the actual thickness of the value, then press vel key to know the speed of sound.

\subsection{Thickness value storage and query}

(1) Press store key 2 seconds into the thickness storage state, display thickness, mm, thickness storage mark M, unit number 1 and data.

(2) Press the query key to find the desired unit.

(3) When the storage unit is selected, the measurement can begin.

(4) long press the store key 2 seconds to display the storage unit number and the value of the thickness of the query button to find.

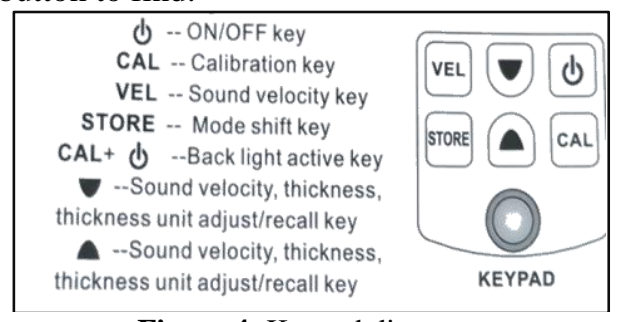

Figure 4. Keypad diagram.

\subsection{Turn on LED lights and automatic shutdown}

In the shutdown state, press and hold Cal before pressing the key to release the light.

\section{Laboratory design}

\subsection{Calibration of ultrasonic thickness gauge}

GM100 type Ultrasonic thickness gauge, the speed of sound to $5900 \mathrm{~m} / \mathrm{s}$ a file, the random $4 \mathrm{~mm}$ test block for measurement calibration, when the screen display value of $4.00 \mathrm{~mm}$, calibration completed. The thickness of the sample is measured by using GM100 intelligent ultrasonic thickness gauge and vernier calliper.

\subsubsection{Measuring thickness of steel plate}

After the calibration, the measured items were measured separately, and the final results were averaged as follows.

Table 1. Steel plate measure thickness value (unit:mm).

The sound velocity of steel plate is $5172 \mathrm{~m} / \mathrm{s}$.

\begin{tabular}{|c|c|c|c|}
\hline micrometer measurement & 0.498 & 0.998 & 1.198 \\
\hline vernier caliper measurement & 0.497 & 0.995 & 1.195 \\
\hline $\begin{array}{c}\text { ultrasonic thickness gauge } \\
\text { measurement }\end{array}$ & 0.5 & 1.0 & 1.20 \\
\hline $\begin{array}{c}\text { the error of ultrasonic } \\
\text { thickness gauge and } \\
\text { micrometer }\end{array}$ & $0.400 \%$ & $\begin{array}{c}0.200 \\
\%\end{array}$ & $\begin{array}{c}0.167 \\
\%\end{array}$ \\
\hline $\begin{array}{l}\text { the error of ultrasonic } \\
\text { thickness gauge andvernier } \\
\text { caliper }\end{array}$ & $0.600 \%$ & $\begin{array}{l}0.500 \\
\%\end{array}$ & $\begin{array}{c}0.417 \\
\%\end{array}$ \\
\hline $\begin{array}{l}\text { micrometer } \\
\text { measurement }\end{array}$ & 1.998 & 3.298 & 5.495 \\
\hline $\begin{array}{l}\text { vernier caliper } \\
\text { measurement }\end{array}$ & 1.998 & 3.295 & 5.498 \\
\hline $\begin{array}{l}\text { ultrasonic } \\
\text { thickness } \\
\text { gauge } \\
\text { measurement }\end{array}$ & 2.00 & 3.30 & 5.50 \\
\hline
\end{tabular}




\begin{tabular}{|c|c|c|c|c|}
\hline $\begin{array}{l}\text { the error of } \\
\text { ultrasonic } \\
\text { thickness } \\
\text { gauge and } \\
\text { micrometer }\end{array}$ & $\begin{array}{c}0.133 \\
\%\end{array}$ & $0.100 \%$ & $\begin{array}{c}0.061 \\
\%\end{array}$ & $\begin{array}{c}0.091 \\
\%\end{array}$ \\
\hline $\begin{array}{l}\text { the error of } \\
\text { ultrasonic } \\
\text { thickness } \\
\text { gauge } \\
\text { andvernier } \\
\text { caliper }\end{array}$ & $\begin{array}{c}0.133 \\
\%\end{array}$ & $0.100 \%$ & $\begin{array}{c}0.152 \\
\%\end{array}$ & $\begin{array}{c}0.036 \\
\%\end{array}$ \\
\hline
\end{tabular}

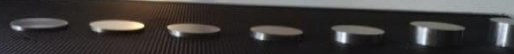

Figure 5. The actual picture of steel plates.

Table 2. Thickness Measurement of steel column(unit: $\mathrm{mm}$ ).

\begin{tabular}{|c|c|c|c|c|}
\hline $\begin{array}{l}\text { micrometer } \\
\text { measurement }\end{array}$ & 14.982 & 19.987 & 24.998 & 49.998 \\
\hline $\begin{array}{l}\text { vernier caliper } \\
\text { measurement }\end{array}$ & 14.985 & 19.990 & 24.995 & 49.995 \\
\hline $\begin{array}{l}\text { ultrasonic thickness } \\
\text { gauge measurement }\end{array}$ & 15.0 & 20.01 & 25.0 & 50.0 \\
\hline $\begin{array}{l}\text { the error of ultrasonic } \\
\text { thickness gauge and } \\
\text { micrometer }\end{array}$ & $0.133 \%$ & $0.115 \%$ & $0.008 \%$ & $0.004 \%$ \\
\hline $\begin{array}{l}\text { the error of ultrasonic } \\
\text { thickness gauge } \\
\text { andvernier caliper }\end{array}$ & $0.100 \%$ & $0.10033 \%$ & $0.133 \%$ & $0.020133 \%$ \\
\hline $\begin{array}{c}\text { micrometer } \\
\text { measurement }\end{array}$ & 74.994 & 99.986 & 149.998 & 199.989 \\
\hline $\begin{array}{c}\text { vernier caliper } \\
\text { measurement }\end{array}$ & 74.990 & 99.980 & 149.995 & 199.980 \\
\hline $\begin{array}{l}\text { ultrasonic thickness } \\
\text { gauge measurement }\end{array}$ & 75.0 & 99.98 & 150 & 200 \\
\hline $\begin{array}{l}\text { the error of ultrasonic } \\
\text { thickness gauge and } \\
\text { micrometer }\end{array}$ & $0.008 \%$ & $0.115 \%$ & $0.006 \%$ & $\begin{array}{c}0.00 \\
6 \%\end{array}$ \\
\hline $\begin{array}{l}\text { the error of ultrasonic } \\
\text { thickness gauge } \\
\text { andvernier caliper }\end{array}$ & $0.013 \%$ & $0 \%$ & $0.003 \%$ & $\begin{array}{c}0.01 \\
0 \%\end{array}$ \\
\hline
\end{tabular}

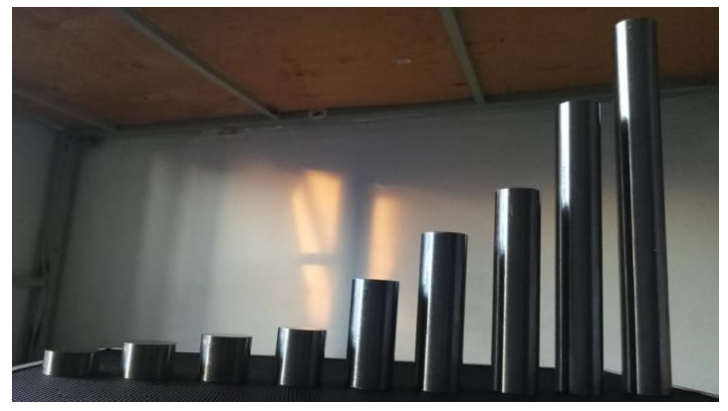

Figure 6. The actual picture of steel column.

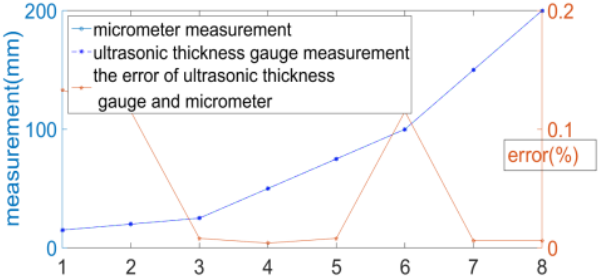

Figure 7. Thickness Measurement of steel column and the error of ultrasonic thickness gauge and micrometer.

It can be found the errors of ultrasonic thickness gauge and micrometer are all under $0.2 \%$, so ultrasonic thickness gauge measurement is believable. 
Table 3. Measurement of bottle thickness (unit: $\mathrm{mm}$ )Sound speed of glass: $5440 \mathrm{~m} / \mathrm{s}$; water speed of sound: $1480 \mathrm{~m} / \mathrm{s}$.

\begin{tabular}{ccc}
\hline & water in bottle & no waterin bottle \\
\hline $\begin{array}{c}\text { enter velocity of } \\
\text { water }\end{array}$ & $\mathbf{0 . 5 0}$ & $\mathbf{0 . 5 0}$ \\
\hline $\begin{array}{c}\text { enter velocity of } \\
\text { glass }\end{array}$ & $\mathbf{2 . 5 0}$ & $\mathbf{2 . 4 0}$ \\
\hline
\end{tabular}

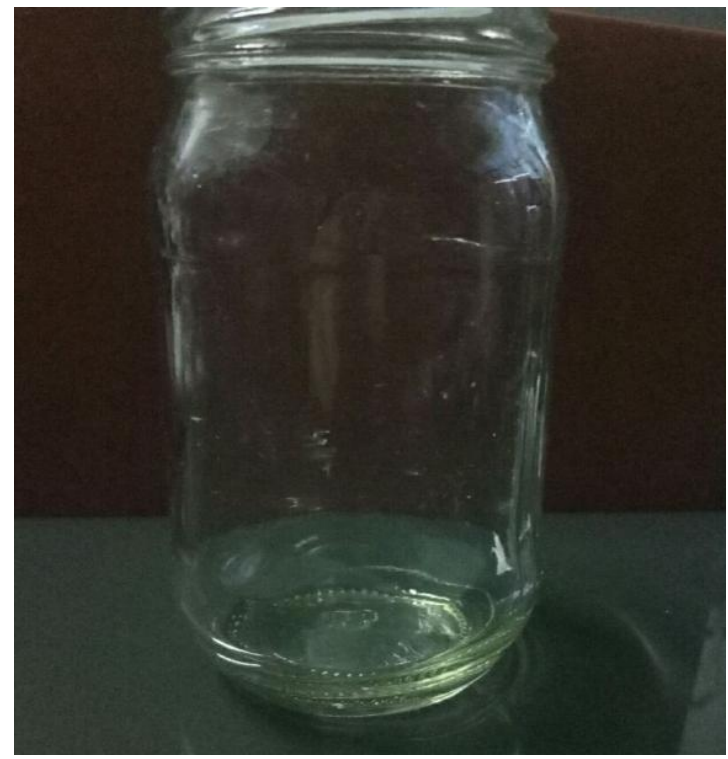

Figure 8The actual picture of bottle

\section{Equations and mathematics}

\subsection{The influence of the material itself}

\subsubsection{The influence of steel material}

The microstructure, particle direction and heat treatment condition of the material will affect the sound velocity in the material during the measurement, and the result has error. The standard test block material is consistent, the organization is homogeneous, and in the steel column of the material type more, the heat treatment condition is different, therefore causes the supersonic in the standard test block and steel plate to live in the sound velocity is also not same, thus causes the measurement result error.

\subsubsection{Effect of glass surface}

The cracks, pits, dust and surface smoothness and roughness of the surface of the glass will result in poor coupling coupling and the change of sound velocity, resulting in the measurement error.

\subsection{The effect of sound velocity}

Because the propagation velocity of sound waves in water and glass is different, the results of the measurement will eventually lead to errors.

\subsection{Factors influencing the measurement method}

The coupling agent is used to remove the air between the probe and the measured object, so that the ultrasonic can effectively enter the detected object, different coupling agent, the coupling effect is different. In addition, when the measurement of the probe force uneven, the coupling layer will change the thickness, resulting in differences in measurement results.

\subsection{The influence of equipment system precision}

The same parameters (wafer diameter, frequency) of the probe, due to the differences in the production process, performance will be different, such as the frequency of probes, spectrum is not at the same time, the probe sound field will have an impact. Commonly used materials for the probe resin, long-term use will make the probe wear, resulting in increased surface roughness, sensitivity reduction, resulting in inaccurate measurement results.

\section{Conclusion}

Ultrasonic thickness tester and ultrasonic flaw detector are different in matching the probe and setting sensitivity. When abnormal readings occur in ultrasonic thickness gauges, an ultrasonic flaw detector is used to confirm the suspected position. The central position of steel plate is most prone to segregation, inclusion, stratification and abnormal coarse tissue, the existence of these imperfections is the main reason for the error of ultrasonic thickness measurement. Improving the internal quality of slab and steel plate is the basic method to reduce thickness error.

\section{ACKNOWLEDGEMENTS}

This work was supported by the Jilin province College Student Project of Tonghua Normal University (No.201708301E).

\section{References}

1. JJF 1059. 1-2012, measurement uncertainty evaluation and expression.

2. JJF 1126-2004, ultrasonic thickness gauge calibration specification.

3. Hui zheng, Shuqing lin. Ultrasonic testing [M]. Beijing: China Labor Social Security Press, 2008.

4. Yuping du. Method for accurate measurement of thickness of steel plate by ultrasonic thickness gauge [J]. China high-tech Enterprise, 2013, (9): 52-54.

5. Jun qiangyang, $\mathrm{Zi}$ ming ye. The thickness of cylinder wall of cylinder body with thin-walled 
cylinder liner is detected by ultrasonic wave [J]. Modern cast iron, 2007,27 (6): 75-79.

6. Zhenhan, Zhi cheng zhang. Determination of the barrel body material and wall thickness of the portable storage pressure type dry powder fire extinguisher [J]. Fire science and Technology, 1989,8 (2): $28-29$ 